\title{
COMPARISON OF FARMS FOCUSING ON PLANT PRODUCTION IN THE PRODUCTION AND ECONOMIC CONDITIONS OF THE SLOVAK REPUBLIC AND LITHUANIA
}

\author{
Patrik ROVNÝ, Faculty of Economics and Management, the Slovak University of Agriculture in Nitra, Trieda Andreja Hlinku 2 , \\ 94976 Nitra, Slovak Republic, patrik.rovny@uniag.sk (corresponding author) \\ Rebecca BRODNANOVÁ, Faculty of Economics and Management, the Slovak University of Agriculture in Nitra, Trieda Andreja \\ Hlinku 2, 94976 Nitra, Slovak Republic, rebecca.brodnanova@gmail.com \\ Katarína BÍROVÁ, Faculty of Economics and Management, the Slovak University of Agriculture in Nitra, Trieda Andreja Hlinku 2, \\ 94976 Nitra, Slovak Republic, xbirovak@uniag.sk
}

\begin{abstract}
In the World there are almost 609 million farms and from it $90 \%$ of farms are family farms. It means that family farm is typical form of farms in the World. This kind of farms are occupying about $80 \%$ of agricultural land and represent about $80 \%$ of food production in the World. Small farms account for $84 \%$ of all farms worldwide, but in terms of agricultural land, they operate only on $12 \%$ of land, which represents about $36 \%$ of the all food production. From the total number of farms, the largest ones (this represents $1 \%$ of farms) operate on size of $70 \%$ of the World's agricultural land.

The aim of this research is to calculate, what is the minimum size of family farm focused on plant production (with typical commodities for both countries) in the Republic of Lithuania and the Slovak Republic. We predict same production and economic al condition in both countries. We calculate with situation, that the family farm will achieve minimum revenue for covering their costs and household expenditures.

In this paper are used the data on farmers from the Slovak Republic and the Republic of Lithuania from the data of business calculations by Ministry of Agricultural and Rural Development of the Slovak Republic and Ministry of Agriculture of the Republic of Lithuania. The presented paper calculates with average household expenditures. The valuse of household expenditures in the Slovak Republic are in value 12795 Euro and average household expenditures in the Lithuania are in value 9889 Euro. Data are used from both countries statistical offices from the year 2019. These expenditures are calculated for one family farm with 2 adults and 2 kids (as average). The results of the paper proved that, according to the algorithm of an average farm focused on crop production, the farm size of 73.25 ha in the Slovak Republic and 73.01 ha in the Republic of Lithuania of agricultural land needs to have one family farm in each country.
\end{abstract}

Keywords: farm size, agricultural land, crop production, crops, costs, prices, revenues, harvests

\section{INTRODUCTION}

In the World there were almost 609 million farms and from it $90 \%$ of farms are family farms. Family farms cover about $80 \%$ of agricultural land and represent about $80 \%$ of food production in the World. Small farms account for $84 \%$ of all farms worldwide, but in terms of agricultural land, they operate only on $12 \%$ of land, which represents about $36 \%$ of the all food production. From the total number of farms, the largest farms (this represents $1 \%$ of farms) operate on size of $70 \%$ of the World's agricultural land (Lowder et al., 2019).

In the EU countries, agriculture is characterized by different farm economic performance and production scale. The most common forms of farms are small farms, especially in areas such as Spain, Scandinavia, and France. On other side are countries with big farms mainly in the central and eastern territories of the EU. These countries are: Bulgaria, Hungary, the Baltic states and also mainly Slovak and Czech Republic where was typical social agricultural system. However, there are also countries in the EU that have not been affected by collectivization in agriculture for example Slovenia and Poland where very large farms are rarely found (Bojnec and Fertö, 2013). There are also EU countries where are typically small farms. These countries are Ireland, Scotland, Scandinavia, all Mediterranean countries, and South-Eastern Europe.

The overall trend in the number of farms is constantly declining. But what we can see that the number of acreage of small farms is declining but on the other side the size of big farms decreasing. The general model of development in the agro-food sector in the European Union shows that the sector will be moved towards greater concentration. Concentrations in land use and agricultural production can endanger the natural environment in particular, to a more severe extent. A reversal of this trend would only occur if the Common Agricultural Policy (CAP) and the national policies of the Member States change their view of smaller farms and start supporting them on a larger scale. Support for small

Copyright () 2021 The Authors. Published by Vytautas Magnus University. This is an open-access article distributed under the terms of the Creative Commons Attribution License (CC BY 4.0), which permits unrestricted use, distribution, and reproduction in any medium, provided the original author and source are credited. 
farms would consist of regulating land sales and prices, land consolidation, or tax changes in favor of family and small farms. Many rural sustainability studies suggest and demonstrate the significant existence of small farms in Europe (Shucksmith and Rønningen, 2011; McDonagh et al., 2017).

The one important indicator describes the evolution of the farm sector is the farm size in hectares. Authors Mockshelland Kamanda (2018) mentioned, that there are two divergent pathways towards the creation of the sustainable agricultural system: sustainable agricultural intensification and agro-ecological intensification.

While in the European Union, according to the Eurostat data from 2019, there are a total of 10.8 million agricultural holdings, in Slovakia there are only 23.6 thousand. The Slovak Republic has on one side small number of farms but on other side Slovakia is country with the biggest farms (by average size in hectares) in the EU. The analysis according to economic size show that among all EU countries there were 6.5 million enterprises (or 59.8\%), which achieved a standard production of more than 2,000 Euro. The utilized agricultural area in the EU-28 was almost 175 million hectares (approximately $40.0 \%$ of the total area), which means an average size of 16.1 hectares per farm.

More than half of European farmers are over 55 and three quarters of all farmers do not work full-time on a farm. The Eurostat study also shows that European agriculture is essentially based on family farming traditions, with $96 \%$ of the total number of farms managed by the owners themselves, $3 \%$ of farms owned by legal entities and $1 \%$ owned by associations.

As in Czechoslovakia, the collectivization of cooperatives took place in the former GDR (German Democratic Republic). The rest are farms that manage above-average areas of land. In eastern Germany, the average farm size is around 230 hectares, in western Germany it is only a fraction - about 40 hectares. For comparison: in Slovakia it is about 80 hectares (Eurostat).

Propaganda and strong pressure from the state meant that by 1960, even the last family farms in the GDR had to leave the business. Farmers in socialism suffered from the typical problems of the time - low savings, low investment, low productivity, and a high burden on the environment. Huge cooperatives used excessive amounts of chemical fertilizers, discharged wastewater on a large scale and raised animals on a large scale. Agriculture nevertheless played an important role in the socialist economy - back in 1989, it employed up to $10.8 \%$ of the workforce (only $4.2 \%$ in West Germany). Estimates say that up to 4,300 businesses have suffered from overemployment, not to mention obsolete machinery and dilapidated stables.

The aim of this research is to calculate, what is the minimum size (size in hectares) of family farm focused on plant production in the Republic of Lithuania and the Slovak Republic. We predict same production and economical condition in both countries. We calculate with situation, that the family farm will achieve minimum revenue for covering their costs and household expenditures.

\section{METHODS}

Data used for calculation of family farms minimal size are from databases of the Ministry of Agricultural and Rural Development of the Slovak Republic and Ministry of Agriculture of the Republic of Lithuania.

We calculate with the algorithm, where the aim is to calculate with the minimal family farm size oriented on plant production (with typical commodities for both countries).

The economic results of agricultural production are affected by:

- natural and climatic conditions,

- production bases / collection areas, livestock numbers /,

- production efficiency / hectare harvests, livestock productivity /,

- unit prices of agricultural production,

- unit prices of inputs / direct costs /,

- unit prices of inputs / direct costs /,

- unit input prices / direct costs /,

- consumption intensity of agricultural production,

- efficiency of inputs into production,

- intensity and productivity of agriculture,

- structure and amount of financial support for farmers.

An algorithm is defined as a final set of rules that describes the sequence of operations to solve a particular type of problem. It has also the following characteristics:

Finality. Each algorithm must end after the final number of steps has been performed. This number of steps can be arbitrarily large (depending on the range and values of the input data), but must be finite for each individual input. Procedures that do not meet this condition may be called calculation methods. A special example of an infinite computational method is a reactive process that continuously reacts with the environment.

Determinability. Each step of the algorithm must be clearly and precisely defined; in each situation, it must be clear what and how it is to be done, how the execution of the algorithm is to continue. Because the common language does not usually provide complete accuracy and unambiguity of expression, programming languages have been designed for writing algorithms in which each command has a clearly defined meaning. The expression of an algorithm in a programming language is called a program.

Entrance. The algorithm usually works with some inputs, quantities that are passed to it before the start of its execution or during its operation. The inputs have defined sets of values that they can acquire. 
Output. The algorithm has at least one output, a quantity that is in the required relation to the specified inputs, and thus forms the answer to the problem that the algorithm solves.

Efficiency. In general, we want the algorithm to be efficient, in the sense that we want every operation required by the algorithm to be simple enough to be able, at least in principle, to be completed in the final time using only pencil and paper (Rovný et. al., 2017).

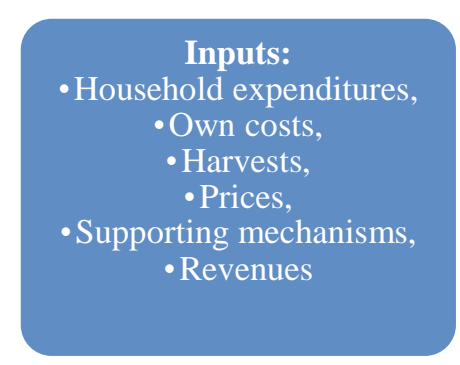

Source: own processing

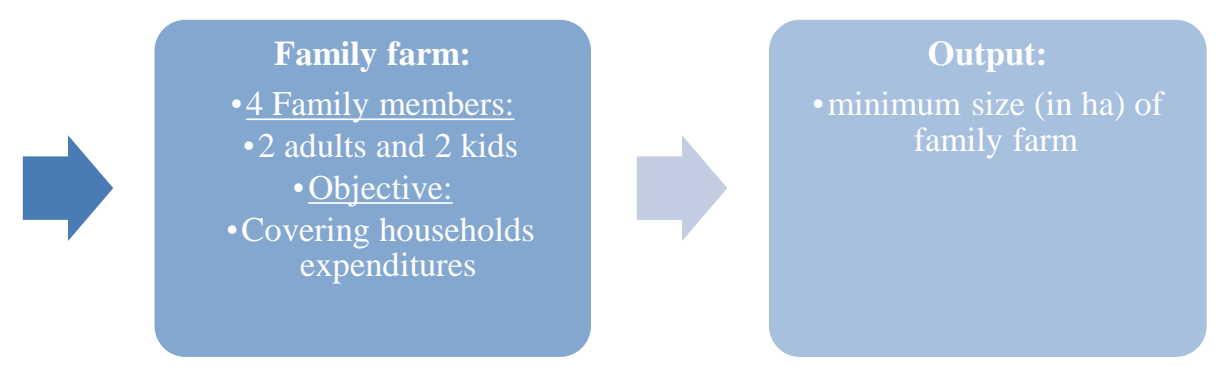

Figure 1. Scheme of Farm size calculation algorithm

Figure 1 describes inputs and outputs of used algorithm.

The presented paper calculates with average household expenditures. The valuse of household expenditures in the Slovak Republic are in value 12,795 Euro and average household expenditures in the Lithuania are in value 9,889 Euro. Data are used from both countries statistical offices from the year 2019. These expenditures are calculated for one family farm with 2 adults and 2 kids (as average).

\section{RESEARCH RESULTS}

During the time period 2005 and 2016, the farms number in the EU 28 fell by about a quarter, what represent 4.4 million farms in the EU. 85\% of farms were mainly small farms with the size of agricultural land below 5 ha. The most affected countries with the largest reductions in postal farms were Poland (number of farms loss: 1.1 million what is in $\%$ change loss $43 \%$ ), Romania (number of farms loss: 0.8 million what is in \% change loss $20 \%$ ), and Italy (number of farms loss: 0.6 million what is in \% change loss $34 \%$ ) over the period under review. The sharpest decline was recorded in relative terms in Slovakia and Bulgaria by almost two-thirds. All Member States were affected by the reduction in the number of farms, except Ireland, where there was no decline in the number of farms.

In 2017, the majority (97.0\%) of EU agricultural holdings were recorded in the classification of family farms. Nine out of ten family farms, representing $94 \%$, have a workforce in the form of family members. In all EU member states, the dominant type of farm is family farms. The only countries that did not have family farms are France, where 27.3 percent of the 0.5 million non-family farms were located, and Estonia with 21.0 percent of non-family farms.

In comparison the average area of farms in the EU-28 in 2019 was 16.6 hectares, in the Slovak Republic it was almost 80.7 hectares and in the Republic of Lithuania 23.2 hectares of agricultural land per one farm.

The calculations are based on an algorithm focuses on the crop rotation principles. The crop rotation system and the sowing procedure determine the soil and natural conditions of the habitat, the material equipments, and economic situation of the farmer. The success of business in this area depends on the market situation and the possibilities of selling cultivated products. It should be noted that if a small farmer wants to effective, must not focus only on common easily cultivated market commodities (cereals, oilseeds, legumes), but also on higher labor productivity commodities. (Lacko-Bartošová, 2005).

In our research we used following crops wheat, barley, sugar beet, oilseed rape, potatoes, and peas. We were calculating with mentioned commodities in our algorithm based on crop rotation. These commodities were selected on the basis of favorable crop cultivation in both countries in Slovakia and Lithuania due to climatic conditions. Focusing on individual plants had a logical justification in the form of greening (and higher subsidies). The main crops grown in the conditions of the Slovak Republic and Lithuania enter the algorithm in the following prevents. In terms of variations, crops are reported per hectare in 2019 (in Slovakia and Lithuania). The data in table 1 are calculated by average share of chosen commodities on arable land in both countries. We used data from the ministries from the Slovak Republic and the Republic of Lithuania.

Table 1. Comparison of countries in indicators: $\%$ share on arable land and hectare harvests (unit: t.ha ${ }^{-1}$ )

\begin{tabular}{|c|c|c|c|c|c|c|c|}
\hline & Indicators & Wheat & Barley & Potatoes & Sugar beet & Rape & Peas \\
\hline Lithuania & Share on arable land in $\%$ & $63 \%$ & $12 \%$ & $1 \%$ & $1 \%$ & $17 \%$ & $5 \%$ \\
\hline Slovak Republic & Share on arable land in \% & $57 \%$ & $18 \%$ & $1 \%$ & $3 \%$ & $21 \%$ & $1 \%$ \\
\hline Lithuania & Harvests (in t.ha $^{-1}$ ) & 4,29 & 3,37 & 18,09 & 70,95 & 2,87 & 2,07 \\
\hline Slovak Republic & Harvests (in t.ha $^{-1}$ ) & 5,07 & 5,43 & 27,93 & 54,29 & 3,29 & 2,33 \\
\hline Difference & (in t.ha $^{-1}$ ) & $-0,78$ & $-2,06$ & $-9,84$ & 16,66 & $-0,42$ & $-0,26$ \\
\hline
\end{tabular}

Source: Ministry of Agriculture from Slovakia and Lithuania (2019) 
There are significant differencies between average harvests of commodities in Lithuania and in Slovakia (table 1). Big differencies are in commodities as sugar beet (16.66 t), potatoes (difference: $9.84 \mathrm{t}$ ) and barley $(2.06 \mathrm{t})$.

In the alghoritm we used variables as the prices which are calculated in unit Euro. $\mathrm{t}^{-1}$ and own costs are calculated in unit t.ha-1 (Table 2).

Table 2. Comparison of countries in indicators: prices (unit: Euro. $\mathrm{t}^{-1}$ ) and own costs (unit: Euro. $\mathrm{t}^{-1}$ )

\begin{tabular}{|c|c|c|c|c|c|c|}
\hline & Indicators & Wheat & Barley & Potatoes & Sugar beet & Rape \\
\hline Lithuania & Prices & 167,30 & 142,50 & 264,70 & 29,96 & 356,50 \\
\hline Slovak Republic & Prices & 160,26 & 169,71 & 415,57 & 22,34 & 357,45 \\
\hline Difference & of Prices & 7,04 & $-27,21$ & $-150,87$ & 7,62 & $-0,95$ \\
\hline Lithuania & Own costs & 784,74 & 539,07 & 6903,64 & 2394,30 & 1121,12 \\
\hline Slovak Republic & Own costs & 927,42 & 868,59 & 10658,85 & 1832,09 & 1285,19 \\
\hline Difference & of Own costs & $-142,68$ & $-329,52$ & $-3755,21$ & 562,21 & $-164,07$ \\
\hline
\end{tabular}

Source: Ministry of Agriculture from Slovakia and Lithuania (2019)

There are significant differencies between prices of commodities in Lithuania and in Slovakia (table 2). Big differencies are in commodities prices as potatoes (difference 150.87 Euro) and barley (27.21 Euro). Differencies are also in own costs mostly in commodities as potatoes (3,755.21 Euro) and sugar beet (562.21 Euro).

Table 3. Algorithm: Calculation of economical results of crop production (case study: the Republic of Lithuania)

\begin{tabular}{|c|c|c|c|c|c|c|c|}
\hline & Wheat & Barley & Potatoes & Sugar beet & Rape & Peas & Total \\
\hline Agricultural land share $(\%)$ & $63 \%$ & $12 \%$ & $1 \%$ & $1 \%$ & $17 \%$ & $5 \%$ & \multirow{6}{*}{$\begin{array}{l}\text { TOTAL } \\
\text { economical } \\
\text { result (in } \\
\text { Euro.ha }^{-1} \text { ) }\end{array}$} \\
\hline Prices $\left(\right.$ Euro. $\left.t^{-1}\right)$ & 167,3 & 142,5 & 264,7 & 29,96 & 356,5 & 254,3 & \\
\hline Own costs $\left(\right.$ Euro.ha $^{-1)}$ & 784,74 & 539,07 & 6903,64 & 2394,30 & 1121,1 & 836,56 & \\
\hline Revenues (Euro.ha ${ }^{-1)}$ & 866,28 & 621,12 & 10552,49 & 2528,76 & 1241 & 937,07 & \\
\hline Harvests $\left(\right.$ t.ha $\left.^{-1}\right)$ & 4,29 & 3,37 & 18,09 & 70,95 & 2,87 & 2,07 & \\
\hline Economical results $\left(\right.$ Euro.ha $\left.^{-1}\right)$ & 81,54 & 82,05 & 3648,86 & 134,45 & 119,91 & 100,51 & \\
\hline $\begin{array}{c}\left.\text { Economical result (Euro.ha- }{ }^{-1}\right) \text { x } \\
\text { agricultural land share }\end{array}$ & 51,44 & 10,1 & 46,82 & 1,34 & 20,41 & 5,32 & 135,44 \\
\hline
\end{tabular}

Source: Ministry of Agriculture in Lithuania and own calculations (2019)

From Table 3 we can see that in Lithuania we are planning with crop rotation with mentioned commodities. Profit of agricultural production focused on plant production is 135.44 Euro.ha $^{-1}$ of agricultural land. It means if every farmer will have this structure of production, will achieve profit 135.44 Euro from each hectare of agricultural land (doesn't matter on size of farm - this is average hectare value). We are planning with situation, that family farm is also employing the other employees needed for production and farm will pay their wages and social costs. In this case family farm will need 73.01 hectares of agricultural land. This calculation is based on household expenditures in amount of 9,889 Euro per year for one family.

Table 4. Algorithm: Calculation of economical results of crop production (case study: the Slovak Republic)

\begin{tabular}{|c|c|c|c|c|c|c|c|}
\hline & Wheat & Barley & Potatoes & Sugar beet & Rape & Peas & Total \\
\hline Agricultural land share $(\%)$ & $57 \%$ & $18 \%$ & $1 \%$ & $3 \%$ & $21 \%$ & $1 \%$ & \multirow{6}{*}{$\begin{array}{l}\text { TOTAL } \\
\text { economical } \\
\text { result (in } \\
\text { Euro.ha }^{-1} \text { ) }\end{array}$} \\
\hline Prices (Euro.t $t^{-1}$ ) & 160,26 & 169,71 & 415,57 & 22,34 & 357,45 & 270,31 & \\
\hline Own costs (Euro.ha ${ }^{-1)}$ & 927,42 & 868,59 & 10658,85 & 1832,09 & 1285,2 & 941,63 & \\
\hline Revenues (Euro.ha ${ }^{-1)}$ & 1023,8 & 1000,8 & 16292,49 & 1934,97 & 1422,7 & 1054,8 & \\
\hline Harvests $\left(\right.$ t.ha $\left.^{-1}\right)$ & 5,07 & 5,43 & 27,93 & 54,29 & 3,29 & 2,33 & \\
\hline Economical results (Euro.ha-1) & 96,37 & 132,21 & 5633,64 & 102,88 & 137,46 & 113,14 & \\
\hline $\begin{array}{l}\text { Economical result }\left(\text { Euro.ha }^{-1}\right) \times \\
\text { agricultural land share }\end{array}$ & 54,69 & 23,31 & 64,37 & 3,12 & 28,19 & 1,06 & 174,74 \\
\hline
\end{tabular}

Source: Ministry of Agriculture in Slovakia, and own calculations (2019)

From Table 4 we can see that in the Slovak Republic we are also planning with crop rotation with mentioned commodities. Profit of agricultural production focused on plant production is 174.74 Euro.ha $^{-1}$ of agricultural land. We are planning with situation, that family farm is also employing the other employees needed for production and farm will pay their wages and social costs. In this case family farm will need 73.01 hectares of agricultural land. This calculation is based on household expenditures of family in the Slovak Republic in amount of 12,795 Euro per year for one family.

\section{CONCLUSIONS}

The average farm size in Slovakia is 81 ha. It is one of the largest areas within the EU member states, where the average is 16 ha and $68 \%$ of farms have less than 5 hectares. It is also said that the basic unit of European agriculture is the "family farm", but the definitions of this type of enterprise are not uniform even within the EU and may refer to a relatively 
small or even a medium-sized farm. The relationship between farm size and production is very actual problem, which is solved in many research projects and also solved in many ministerial materials (Ladvenicová, Miklovičová, 2015).

We calculate with the algorithm, where the aim of this research is to calculate with the minimal size of family farm oriented on plant production (with typical commodities for both countries). In this paper are used the data on farmers from the Ministry of Agricultural and Rural Development of the Slovak Republic and Ministry of Agriculture of the Republic Lithuania.

The presented paper calculates with average household expenditures for one family with 4 members. The valuse of household expenditures in the Slovak Repiblic are in value 12,795 Euro and average household expenditures in the Lithuania are in value 9,889 Euro. Data are used from both countries statistical offices froim the year 2019. These expenditures are calculated for one family farm with 2 adults and 2 children (as average).

The results of the paper proved that, according to the algorithm of an average farm focused on crop production, the farm size of 73.25 ha in the Slovak Republic and 73.01 ha in the Republic of Lithuania of agricultural land needs to have one family farm in each country.

Acknowledgements. The paper is a part of the international project Erasmus+ KA2 Strategic Partnerships. Viability of small farms managed by young farmers under new "farm-to-fork" strategy (VISYFARM), solved at the Faculty of Economics and Management, Slovak University of Agriculture in Nitra. (Main coordinator: Czech University of Life Science in Prague, Czech Republic).

This paper was created with the support of the Erasmus+ Programme of the European Union, Jean Monnet Centre of Excellence project "Centre of Excellence for European Agri-Food Chain - CEEAG" No. 611446-EPP-1-2019-1-SK-EPPJMO-CoE. The European Commission support for the production of this publication does not constitute an endorsement of the contents which reflects the views only of the authors, and the Commission cannot be held responsible for any use which may be made of the information contained therein.

\section{REFERENCES}

1. Atkočiūnienè, V., Petruliene, D. 2014. Impact of Multifunctional Agriculture on Territorial Competitiveness: Theoretical Approach. Economics and Rural Development, Vol. 10, pp. 7-15. https://doi.org/10.15544/erd.2014.007

2. Bojnec, Š., Latruffe, L. 2013. Farm size, agricultural subsidies and farm performance in Slovenia. Land Use Policy, Vol. 32, pp. 207-217. https://doi.org/10.1016/j.landusepol.2012.09.016

3. Eurostat. 2016. Agriculture, forestry and fishery statistics, 2015 edition. Eurostat Statistical Books. Luxembourg: Publications Office of the European Union.

4. Kowalczyk, C., Źróbek-Różańska, A., Źróbek, A., Kryszk, H. 2021. How does government legal intervention affect the process of transformation of state-owned agricultural land? The research methods and their practical application. Land Use Policy, Vol. 111, 105769. https://doi.org/10.1016/j.landusepol.2021.105769

5. Knickel, K., Redman, M., Darnhofer, I., Ashkenazy, A., Calvão Ch., Šūmane, S., Tisenkopfs, T., Zemeckis, R., Atkočiūnienė, V., Rivera, M., Strauss, A., Kristensen, L., Schiller, S., Koopmans, M., Rogge, E. 2018. Between aspirations and reality: Making farming, food systems and rural areas more resilient, sustainable and equitable. Journal of Rural Studies, Vol. 59, pp. 197-210. https://doi.org/10.1016/j.jrurstud.2017.04.012

6. Lacko-Bartošová, M. (2005): Sustainable and ecological agriculture. Nitra : VES SPU, 2005, 575 p.. ISBN 80-69-556-3

7. Ladvenicová, J., Miklovičová, S. 2015. The Relationship Between Farm Size and Productivity in Slovakia. Journal on Bioeconomy and Sustainable Development, Vol. 4, no. 2, p. 46-50. https://doi.org/10.1515/vjbsd-2015-0011

8. Laurent Piet. Recent trends in the distribution of farm sizes in the EU. 149. EAAE Seminar 'Structural change in agri-food chains: new relations between farm sector, food industry and retail sector', Institut National de Recherche Agronomique (INRA). UMR Structures et Marchés Agricoles, Ressources et Territoires (1302)., Oct 2016, Rennes, France.

9. Levesque, R. 2016b. Introduction to the rountable discussion. In Future land use of rural and peri-urban areas, AEIAR 50th anniversary. Bruxelles (Belgium).

10. Lowder, S. K., Sánchez, M. V., Bertini, R. 2019. Farms, family farms, farmland distribution and farm labour: What do we know today? FAO Agricultural Development Economics Working Paper 19-08. Rome, FAO.

11. Mach, J., Dvořák, M. and Hošková, P. 2018. EU Milk and Dairy Market Changes and Impact of Globalisation Trends. In I 18th International Scientific Conference. Globalization and its socio-economic consequences (Part III.-Economic Progress in PostSoviet Countries), Rajecke Teplice, Slovak Republic, Zilina, Slovakia, ZU-University of Zilina, pp. 1204-1212.

12. Martins, C., Tosstorff, G. 2011. Large farms in Europe. Less than $1 \%$ of European farms occupy $20 \%$ of the Utilised Agricultural Area. Eurostat Statistics in Focus.

13. McDonagh J., Farrell M., Conway S. 2017. The Role of SmallScale Farms and Food Security. Sustainability Challenges in the Agrofood Sector, pp. 33-47. https://doi.org/10.1002/9781119072737.ch2

14. Rovný, P. Dobák, D., Kádeková, Z., Kubicová, L., Smutka, L. 2017. Minimum land requirements for average family income produced in the Slovak agriculture. In Agrarian Perspectives XXVI. Competitiveness of European Agriculture and Food Sectors, Proceedings of the 26th International Conference, Prague, Czech Republic 2017, pp. 327-334.

15. Shucksmith M., Rønningen K. 2011. The Uplands after neoliberalism? - The role of the small farm in rural sustainability. Journal of Rural Studies, Vol. 27, pp. 275-287. https://doi.org/10.1016/j.jrurstud.2011.03.003 